Ethiopian Journal of Environmental Studies \& Management 8(6): 720 - 726, 2015.

ISSN:1998-0507

doi: http://dx.doi.org/10.4314/ejesm.v8i6.10

Submitted: May 03, 2015

Accepted: September 09, 2015

\title{
USAGE OF DEMAND-DRIVEN EXTENSION SERVICES BY FARMERS IN AGRICULTURAL ZONES IN NIGER STATE, NIGERIA
}

*UMAR, S.I., OLALEYE, R.S. AND ADENIJI, B.O.

Department of Agricultural Economics and Extension Technology, Federal University of Technology, Minna, Niger State, Nigeria

\begin{abstract}
The study examined the usage of demand-driven extension services by farmers in agricultural zones in Niger State, Nigeria. To achieve the study objectives, multi-stage sampling technique was used to select a total of 377 respondents for the study. Validated interview schedule was used to generate data for the study. Data collected were analyzed using both descriptive and inferential statistics. Result of the study showed that majority (60.7\%) of the respondents used demand-driven extension services four times in a year. Finding also indicated that majority of the respondents demanded for information on storage, improved seeds/planting materials and processing technologies. The result of analysis of variance further revealed that there was significant difference in the usage of demand-driven extension services by farmers in the agricultural zones $(F=31.09, P<0.05)$. It was therefore recommended that demand-driven extension service providers should make concerted efforts to sensitize the farmers to make them more receptive of their services. In order to create condition for optimal performance of service providers in the agricultural zones, it was suggested that government should consider the feasibility of agro-diversity approach to demand-driven extension service delivery.
\end{abstract}

Key Words: Demand-driven, Extension, Usage, Agricultural Zones, Niger State

\section{Introduction}

In recent times, thinking and practice about agricultural extension services has changed toward pluralistic modes of providing extension services. Major reform trends around the world include: decentralization; contracting; privatization; cost sharing; and the involvement of Non Governmental Organizations' private providers; and farmer-based organizations (Katz, 2006). The reform also emphasized that agricultural extension services must be demand-driven.
Demand-driven in this context is defined by Neuchatel Group (2006) as what farmers ask for, need and appreciate so much that they are willing to invest their resources, such as time and money, in order to receive the services. The demand-driven services are characterized by accountability of service providers to the users (farmers), and by the ability of farmers to choose freely among service providers. The emergence of demand-driven model for extension was facilitated in recent years by Neuchatel Group, which is an informal 
group of bilateral and multilateral cooperation agencies and institutions involved in sub-Saharan African countries.

The main principles of demand-driven extension service systems, as expressed by the group include: (i) deepening decentralization of extension services; (ii) changing the roles of extension agent from adviser or teacher to facilitator; (iii) increasing farmers' influence and control over the extension services; (iv) helping small -scale farmers to link with market opportunities; and (v) contracting out of services.

Informed by demand-driven perspectives, many countries initiated efforts to revitalize agricultural extension services which have resulted into many reforms such as decentralization, contracting/outsourcing and public-private partnership. In addition, new actors and stakeholders have entered the scene to provide and finance extension services, including non-governmental organizations (NGOs), farmer associations and community- based organizations (Katz, 2006).

In buttressing this point, Anderson and Feder (2004) reported that the emerging demand-driven extension system provides new alternatives to solve the problems of complexity of extension services caused by the nature of agricultural production; the associated constraints of monitoring, evaluation and impact assessment, the challenge to promote learning processes and establish feedback linkages and the problem to ensure political commitment and fiscal accountability inherent in providing agricultural extension services. The demand-driven extension service system also addresses the challenges related to the financing and promotes delivering of agricultural extension services that are best suited to community- specific frame conditions, product or commodityspecific needs and political or economic priorities. Its purpose is to bring about shift from supply-driven to demand-driven extension services.

However, the recent emphasis on making agricultural extension services demand-driven has raised fundamental issue such as will demand-driven extension services lead to greater equity in terms of the usage of demand-driven extension service by the farmers in different locations? Thus, the specific objectives of this study are to examine the use of demand-driven extension services by the farmers in agricultural zones and to determine type of information/technology demand by the respondents in the agricultural zones.

\section{Hypothesis}

There is no significant difference in the usage of demand-driven extension services by the farmers in the three Agricultural Zones in the state.

\section{Literature Review}

Rivera and Alex (2004) stressed that demand-driven is a relatively recent label for an idea that has been around since researchers begin to write about extension as an academic discipline. The major objective of demand-driven agricultural extension services as expressed by Neuchatel Group (2006) is to increase agricultural income and household food security of small-scale and medium-scale farmers by providing access to extension services that have the content and quality farmers ask for. Gustafson (2004) reported that in Kenya, Farmers Field Schools (FFS) extension method was introduced to influence changes through demand-driven extension services. The author further stressed that the participating farmers' groups improved their output, income and food security, and expanded their activities 
to take new responsibilities and tasks. In the context of Transformation of Agricultural Extension under Participatory District Planning in Zimbabwe, Chipaka and Friis-Hansen (2004) revealed that the participatory demand-driven extension approach chanced the way farmers relate with researchers and acquired useful practical field experiences during implementation. The approach also enhanced farmer's ability to improve natural resources management and agricultural production. In a similar reform, Currle and Hoffmann (2004) said in Semiprivatized Extension Circles in Germany, demand-driven extension approach brought about improvement in working relationship and quality of service for farmers, while extension services become more specialized and targeted to the specific needs of the farmers. The literature reviewed indicates that demand-driven extension services improved farmers' access to services. However, location factor can affect demand-driven extension service delivery and its usage.

\section{Methodology}

This study was conducted in Niger State. The State is located in the Southern Guinea Savanna ecological zone of Nigeria. Rainfall is steady and is evenly distributed usually between May and November each year, varying from $1,100 \mathrm{~mm}$ in the North to $1,600 \mathrm{~mm}$ in the South. The major arable crops grown include maize, cassava, vegetables, rice, yam, millet, cocoyam, potato, cowpea, groundnut, guinea corn, fruits and sugarcane. Livestock reared include goat, sheep, cattle, chicken and donkey (Niger State Agricultural Development Project, 2002).

The sample population for the study was made up of all farmers participating in the demand-driven extension delivery system of National Fadama Development Project II in Niger State, Nigeria. Multistage sampling technique was used to select the respondents from the three Agricultural Zones in the State (Zones I, II and III). At the first stage, three Local Government Areas (LGAs) were randomly selected from each zone, while in the second stage three Fadama Associations (FAs) were randomly selected from each LGA. At the third stage, two Fadama User Groups (FUGs) were selected from each FA. In all, a total of 377 farmers were selected for the study at the fourth stage. Primary data were collected through interview schedule and the data collected were analyzed using descriptive statistics, while the study hypothesis was tested using analysis of variance

\section{Analysis of variance}

Analysis of variance (ANOVA) was used to determine whether there is difference in the usage of demand-driven extension services by the farmers in the three Agricultural Zones in the State. The use of ANOVA is more appropriate in a test like this where there are more than two categories of Agricultural Zones. Agricultural Zones have different factors that may influence the tendency of farmers to utilize demand-driven extension services depending on location.

\section{Results and Discussion}

\section{Usage of Demand-Driven Extension Services}

Majority of the respondents i.e. $69.8 \%$, $63.3 \%$ and $49.2 \%$ in agricultural zones I, II and III respectively, indicated that they had four extension contacts through demanddriven extension services in a year (Table 1). While $43.7 \%, 37.6 \%$ and $32.5 \%$ of the respondents respectively, in agricultural zones I, II and III had three extension contacts with demand-driven extension 
service providers in a year. All over the zones, $60.7 \%$ of the respondents had four extension contacts in a year through demand-driven extension delivery system, which implies that most of the respondents used demand-driven extension services four times in a year. If we accept the view of
Jiriko (2005) who reported that $37 \%$ of the farmer respondents in Kaduna State had no extension contact, then this result points to the ease of accessing extension services through demand-driven extension delivery system.

Table 1: Distribution of respondents based on number of extension contact per year

\begin{tabular}{lcccc}
\hline Extension contact & Zone I & Zone II & Zone III & Total \\
\hline & $\mathrm{F}(\%)$ & $\mathrm{F}(\%)$ & $\mathrm{F}(\%)$ & $\mathrm{F}(\%)$ \\
No contact & $(\mathrm{n}=126)$ & $(\mathrm{n}=125)$ & $(\mathrm{n}=126)$ & $(\mathrm{n}=377)$ \\
Twice & $2(1.6)$ & $1(0.8)$ & $1(0.8)$ & $4(1.1)$ \\
Thrice & $1(0.8)$ & - & - & $1(0.3)$ \\
Four times & $55(43.7)$ & $47(37.6)$ & $41(32.5)$ & $143(37.9)$ \\
& $88(69.8)$ & $79(63.2)$ & $62(49.2)$ & $229(60.7)$ \\
\hline
\end{tabular}

\section{Technologies Demanded}

Table 2 revealed that in agricultural zone I, $96.2 \%$ of the respondents demanded for information on storage. This was followed by information on improved seeds/planting materials (95.2\%), while $96.0 \%$ of the respondents asked for information on processing technologies. Moreso, in agricultural zone II, 92.8\%, $91.2 \%$ and $88.0 \%$ of the respondents respectively, demanded for information on storage, improved seeds/planting materials and processing technologies. While in agricultural zone III, More information was demanded on livestock breeds with $80.1 \%$ response rate. This was followed by information on livestock pasture/feeds (71.4\%) and storage technologies (70.6\%). On the whole, $86.7 \%$ of the respondents demanded for information on storage technologies and $85.1 \%$ asked for information on improved seeds/planting materials, while $83.8 \%$ requested for information on processing. Other types of information and technologies demanded by the respondents are in this order: crop management (60.2\%); livestock breeds $(60.0 \%)$; marketing strategies (53.8\%); livestock feeds $(50.6 \%)$; weed control
(50.3\%); veterinary services (49.3\%); chemical fertilizer (47.4); soil water conservation (37.9\%); Leadership skill training (23.8\%); aquaculture (21.7\%); agro forestry $(13.2 \%)$; and bee keeping (1.3\%). Those demands revealed the areas of agricultural information needs of the respondents in the study area, suggesting that the respondents are committed to receiving services on those agricultural technologies or activities, depending on their farming characteristics. In relation to this, Birner and Anderson (2007) said that farmers are usually encouraged demanding for extension services that relate to their personal interest and needs.

One important point of note was that more information were demanded on crop production technologies in Agricultural Zone I and II which are largely crop production based, while most of the demanded information on livestock production technologies and other related activities were mostly from agricultural zone III where more animals are reared. Thus, the agricultural information demanded by the respondents was tied to the agricultural activities in the zones. 
Table 2: Distribution of respondents according to type of information/technology demanded in agricultural zones

\begin{tabular}{lcccc}
\hline $\begin{array}{l}\text { Information/technology } \\
\text { demanded* }\end{array}$ & $\begin{array}{c}\text { Zone I } \\
\mathrm{F}(\%) \\
(\mathrm{n}=126)\end{array}$ & $\begin{array}{r}\text { Zone II } \\
\mathrm{F}(\%) \\
(\mathrm{n}=125)\end{array}$ & $\begin{array}{r}\text { Zone III } \\
\mathrm{F}(\%) \\
(\mathrm{n}=126)\end{array}$ & $\begin{array}{c}\text { Total } \\
\mathrm{F}(\%) \\
(\mathrm{n}=377)\end{array}$ \\
\hline Improved seed/planting material $120(95.2)$ & $114(91.2)$ & $87(69.0)$ & $321(85.1)$ \\
Chemical fertilizer & $72(57.1)$ & $91(56.8)$ & $36(28.6)$ & $179(47.4)$ \\
Soil conservation & $51(40.5)$ & $59(47.2)$ & $33(26.2)$ & $143(37.9)$ \\
Crop management & $97(77.0)$ & $89(71.2)$ & $41(32.5)$ & $227(60.2)$ \\
Weed controls & $71(56.3)$ & $74(59.2)$ & $45(35.7)$ & $190(50.3)$ \\
Storage technology & $122(96.2)$ & $116(92.8)$ & $89(70.6)$ & $327(86.7)$ \\
Livestock breeds & $64(50.8)$ & $69(55.2)$ & $101(80.1)$ & $234(62.0)$ \\
Livestock pasture/feeds & $50(39.7)$ & $51(40.8)$ & $90(71.4)$ & $191(50.6)$ \\
Veterinary services & $49(38.9)$ & $53(42.4)$ & $84(66.7)$ & $186(49.3)$ \\
Agro-forestry & $21(16.7)$ & $10(8.0)$ & $19(15.1)$ & $50(13.3)$ \\
Bee keeping & - & $5(4.0)$ & - & $5(1.3)$ \\
Aquaculture & $20(15.9)$ & $33(26.4)$ & $29(23.0)$ & $82(21.7)$ \\
Processing & $121(96.0)$ & $110(88.0)$ & $85(67.5)$ & $316(83.8)$ \\
Marketing strategies & $70(55.6)$ & $68(54.4)$ & $65(51.6)$ & $203(53.8)$ \\
Leadership skill training & $30(23.8)$ & $27(21.6)$ & $33(26.2)$ & $90(23.8)$ \\
\hline
\end{tabular}

*Multiple responses

ANOVA for the usage of demand-driven extension services by farmers in the agricultural zones

From the analysis of variance (ANOVA) in Table 3, F-calculated (31.09) was greater than F-tabulated (4.71) at $0.05 \%$ level of significance. This signifies that there was significant difference in the usage of demand-driven extension services by the farmers in the three agricultural zones in the State. Further analysis of ranking of the zones revealed that Agricultural Zone I had the highest mean of 3.78; followed by Agricultural Zone II with a mean figure of 3.54, while Agricultural Zone III had the least mean of 3.31.This implies that there was more usage of demand-driven extension services in Agricultural Zones I and II than Agricultural Zone III of the State. This can be attributed to the presence of more agricultural research institutes, institutions and agencies in Agricultural Zones I and II, which facilitated provision of services because of proximity to sources of information. This finding confirmed the result of previous study by Adjaye (2008) who reported that farmers who live closer to a research station are more likely to be perceptive to the benefit of the extension services. Also, Nambiro et al. (2005) stressed that the closer the farmer is to the source of extension, the more likely he or she is to seek and use its services. 
Table 3: ANOVA result for differences in the usage of demand-driven extension services by respondents in agricultural zones of the state

\begin{tabular}{|c|c|c|c|c|c|c|}
\hline $\begin{array}{l}\text { Source of } \\
\text { variation }\end{array}$ & $\begin{array}{l}\text { Sum of } \\
\text { squares }\end{array}$ & Df & $\begin{array}{l}\text { Mean } \\
\text { square }\end{array}$ & F-calculated & $\mathrm{P}$ value & Decision \\
\hline Zones & 13.61648638 & 2 & 6.80824319 & 31.09 & $.0001 *$ & Significant \\
\hline Residual & 81.91136508 & 370 & 0.21901435 & & & \\
\hline Total & 95.52785146 & 372 & & & & \\
\hline \multicolumn{7}{|c|}{ Zone I $(3.77778)^{1}$} \\
\hline \multicolumn{7}{|c|}{ Zone II $(3.53968)^{2}$} \\
\hline \multicolumn{7}{|c|}{ Zone III $(3.31200)^{3}$} \\
\hline
\end{tabular}

\section{Conclusion}

From the findings of the study, it can be concluded that majority of the respondents used demand-driven extension services four times in a year. More information was demanded on storage, improved seeds/planting materials and processing technologies. There was significant difference in the usage of demand-driven extension services by the farmers in the three agricultural zones in the State.

\section{Recommendations}

In order to improve farmers' access to agricultural extension services and increase usage of extension services, it was recommended that demand-driven extension delivery system should be extended to other category of farmers in the state.

To take care of observed differences in the demand and usage of extension services by the respondents in the three agricultural zones in the state, government may consider the feasibility of agro-diversity approach to demand-driven extension service provision, in order to create condition for optimal performance of service providers in the agricultural zones in the state.

Demand-driven extension service providers should make concerted efforts to sensitize the farmers to make them more receptive of demand-driven extension services. This can be done through farmers' cooperative associations, radio and television and the timing for awareness jingle must coincide with the target audience prime time.

\section{References}

Adjaye, J.A. (2008). Factors affecting the adoption of soil conservation measures: A case study of Fijian cane farmers. Journal of Agricultural and Resource Economics 33 (1):99-117.

Anderson, J.R. and Feder, G. (2004). Agricultural Extension: Good Intentions and hard realities. World Bank Research Observer, 19(1): 4160.

Birner, R. and Anderson, J. R. eds. (2007). How to make Agricultural Extension Demand-Driven: The case of India's Agricultural Extension Policy. IFPRI Discussion Paper 00729, Retrieved May 17, $2010 \quad$ from http://books.google.com.

Chipika, S. and Friis-Hansen, E. (2004). Transformation of Agricultural Extension under participatory District planning: comparative Experience in Shurugwi and Gwanda Districts. In: Rivera, W. and Alex, G. (eds) 
Volume 3. Demand-driven Approaches to Agricultural Extension: Case Studies of international Initiatives. Agricultural and Rural Development Discussion Paper 10 Extension Reform for Rural Development. The World Bank, Washington, D.C. Pp 73-80.

Currle, J. and Hoffmann, V. (2004). Semi privatized Extension Circles in the State of Baden-Wurttemberg In: Rivera, W. and Alex, G. (eds) Volume $3 . \quad$ Demand-driven approaches to Agricultural Extension: Case Studies of international Initiatives. Agricultural and Rural Development Discussion Papers10 Extension Reform for Rural Development. The World Bank, Washington, D.C. Pp 83-90.

Gustafson, D.J. (2004). Supporting the Demand for change-recent project experience with farmer learning grants. In: Rivera, W. and Alex, G. (eds) Volume 3. Demand-driven Approaches to Agricultural Extension: Case Studies of International Initiative. Agricultural and Rural Development Discussion Paper 10 Extension Reform for Rural Development. The World Bank, Washington, D.C. Pp 22-30.

Jiriko, R.R.K. (2006). Socio-economic farmers affecting the performance of women in food production. In Madukwe, M.C. (eds). Changing perspectives in Extension Innovation System in Nigeria. Proceedings of the $11^{\text {th }}$ Annual National Conference of the Agricultural Extension Society of Nigeria, held at University of Abeokuta, Pp 264-270.

Katz, E. (2006). Agricultural servicescurrent state of the policy debate. In: rural Development news 2006/pp.813, Retrieved June 15, 2011 from http://www.ibi.ch/internat/servces/pu bl/bn/2006/01/ agricultural-servicescurrent. Pdf.

Nambiro, E. Omiti, J. and Muguneri, L. (2005). Decentralization and Access to Agricultural Extension Services in Kenya. Strategies and Analysis for growth and Access, SAGA Working Paper No.9.Pp 1-11.

Neuchatel Group (2006). Demand-driven agricultural advisory services. Landau, Switzerland, Published by Swiss centre for agricultural extension and rural development. Pp1-30.

Niger State Agricultural Development Project (2002). Impact Study Final Report, Pp. 1-128.

Rivera, W. M. and Alex, G. (eds) (2004). Demand-driven approaches to agricultural Extension: case studies of International Initiative, volume 3. Agricultural and Rural Development Discussion paper No 10, the World Bank, Washington D.C. U.S.A. Pp 19 . 